\title{
Notas Therapeuticas
}

\author{
Tratamento da febre typhoide, \\ pelo prof. Rubião Meira.
}

\begin{abstract}
A FEBRE typhoide é uma dessas molestias em que o tratamento é o mais difficil, pois que innumeras são as indicações a preencher, uma vez que as complicaçôes de habito costumam apparecer repentinamente, E, o intuito do medico não é combatel-os, mas sim evitar o seu apparecimento. Os tratamentos divergem e cada medico a trata a seu modo. Uns, dão, desde cedo os banhos, de accordo com o velho tratamento. Mas, nem sempre isso é possivel e raro é o doente cuja resistencia não cede e que pode supportar o incommodo de levantar se para a banheira, por mais proxima se ache do leito. Ao cabo de alguns dias o cansaço é enorme e é com difficuldade que se consegue pôr esses individuos no banho. Em todo o caso é sempre um bom tratamento e que no inicio da molestia tem sua precisa indicação. Banho quasi frio, panno com agua gelada na cabeça, durante 15 minutos, seguido ou não de um grog quente - deve ser por isso usado, sem entretanto, nisso, consistir só a therapeutica, como querem alguns. $\mathrm{O}$ banho tem grandes propriedades therapeuticas, devendo ser contada como excellente, além da acção anti-thermica, a sedativa sobre os centros nervosos. Surge porem uma complicação, como a hemorrhagia intestinal e ja se não têm mais occasião de continuar com o seu emprego. Outros usam os envoltorios frios. São bons. Mas, eu tenho visto accidentes desagradaveis, com elles. Nas creanças e nos velhos ja observei o apparecimento de bronchites e broncho-pneumonias que põem, as vezes, a vida em perigo. Alguns ha que preferem os antithermicos chimicos. E' o pyramido; a phenacetina, o quinino, a antipyrina que entram em scena. Não os emprego. Mesmo, porque, alem de depressivos sobre o centro circulatorio, têm o inconveniente de perturbarem a curva thermica e não deixarem se aprecie convenientemente a evolução da molestia. E, no emtanto, as familias procuram sempre o medico com o intuito de darem um remedio que "corte a febre" - Eu costumo responder que infelizmente não ha thesoura capaz de fazel-o, pois que se corre o risco de cortar tambem a vida do doente. Outros empregam o electrargol ou o lantol. De facto é bôa medicação. Eu aliás nunca consegui grande cousa com essas injecções. Na pneumonia não prescindo do seu uso, mas raramente, ultimamente, lanço mão dellas na dothienenteria. Outros
\end{abstract}


collocam sómente gelo no ventre e gelo no coração - este com o intuito de conseguir tonificar o centro cardiaco e abaixar a febre; aquelle com a intenção de evitar complicações intestinaes, permittindo tambem o decrescimento das altas temperaturas. No mais é sempre a mesma cousa: Dieta, que eu não faço como os medicos allemães, dando apenas caldos e chá, não permittindo a riqueza de alimentos daquelles clinicos; tonicos cardiacos, para evitar o apparecimento de myocardite; diureticos, para facilitar o funccionamento da depuração organica; sulfato de sodio diariamente para deixar sempre desembaraçados os intestinos; oleo camphorado para manter as forças, ou pelo menos para dar a illusão que se as está mantendo com essa medicação. Isto eu faço, como fazem todos os clinicos - tratar o doente, com o intuito de evitar a intercurrencia de complicações, que tanto desnorteam os medicos e os entristecem. Mas, eu quero é frizar o tratamento que uso e com o qual sempre me tenho dado bem. Emprego-o logo feito o diagnostico e tenho encontrado doentes em periodo adeantado e usado com excellentes resultados. Quero referir-me á vaccinação anti-typhica curativa. Lanço mão das injecções do Instituto Serotherapico de Milão São ampolos dosados de 25 a 500 milhões de germens; nunca chego a 100 milhões. De 3 em 3 dias faço uma picada, repetindo as injecções, o que quer dizer que faço 25 milhões, repito os $25 \mathrm{mi}$ lhões; 50 milhões - repito; 75 milhões e não preciso ir adeante porque o resultado é desde logo patente. A gravidade da molestia immediatamente desapparece, os phenomenos se atenuam, o estado geral melhora, cede o delirio quando existe.

Tenho muitas observações que me levam a affirmar que é meio therapeutico seguro e que não pode ser desprezado, antes deve ser sempre utilizado. Entre multiplos casos que tenho tratado não me esqueço de uma senhora que se poderia considerar perdida - tal o seu estado; delirante, em plena carphologia, ventre abaulado, anciedade intensa, pulso fugidio e rapido, physionomia cadaverica, tudo indicando desespero do caso. Com as injecções, de que não fiz mais que tres, tudo serenou e a molestia seguiu o seu curso natural, tendo essa doente se restabelecido. Ao lado do gelo no ventre, do sulfato de sodio, dos tonicos cardiacos, é a medicação que eu emprego e que conselho a todos os meus alumnos. 